\title{
Phytochemical Analysis and Antimicrobial Activity of Different Extracts of Clematis gouriana. Roxb Flower on Multi Drug Resistance oral Pathogens
}

\author{
B.G. Yogesh ${ }^{1}$, P.Sheshadri ${ }^{2}$, N. Anees Ahmed ${ }^{3}$, A.R.Gulnaz ${ }^{4}$ and R.Vatsala ${ }^{1}$ \\ ${ }^{1}$ Department of Conservative Dentistry and Endodontics, Farooqia Dental College \& Hospital \\ Mysore-21, Karnataka, India \\ ${ }^{2}$ Department of Periodontics and Implantology, Farooqia Dental College \& Hospital \\ Mysore-21, Karnataka, India \\ ${ }^{3}$ Department of Oral and Maxillofacial Surgery, Farooqia Dental College \& Hospital \\ Mysore-21, Karnataka, India \\ ${ }^{4}$ Department of Biochemistry, Farooqia Dental College \& Hospital Mysore-21, Karnataka, India \\ *Corresponding author
}

Keywords

Clematis gouriana Roxb, Multidrug resistance, Oral pathogens, Resazurin, Phytochemicals.

\section{Article Info}

Accepted:

20 February 2016 Available Online: 10 March 2016

\section{A B S T R A C T}

Different extract of Clematis gouriana Roxb flower was assessed for its phyto constituents and in vitro antimicrobial activity against multidrug resistance (MDR) oral pathaogens. Phytochemical analysis revealed the presence of various important secondary metabolites like alkaloids, flavonoids, phenol, emodins, coumarins etc. Among the different extracts of Clematis gouriana Roxb flower, ethanol extracts was found to be more potent against all the MDR oral pathogens tested, significant activity was seen against $E$. coli with the zone of inhibition of $13 \mathrm{~mm}$ and the MIC value of $0.875 \mathrm{mg} / \mathrm{ml}$, followed by against both $S$. aureus and $S$. mutants $(12 \mathrm{~mm})$ with MIC value of $0.1 .75 \mathrm{mg} / \mathrm{ml}$ and $0.875 \mathrm{mg} / \mathrm{ml}$ respectively.

\section{Introduction}

Medicinal plants are being used for the treatment of various diseases from the pre historic period in the traditional systems of medicine which is still in practice. With the progress in scientific research of herbals, medicinal herbs are considered to have a pivotal role in this synthetic era. These medicinal plants find wide application in pharmaceutical, cosmetic and food industries.
As the herbal products are safer in contrast to the synthetic, side effects of several synthetic drugs and development of resistance to currently used drugs for infectious diseases have led to increased demand on the use of plant materials as a source of medicine for various human ailments. Most of the human pathogens have developed resistant against many commonly used synthetic antibiotics in the treatment of various infections and communicable 
diseases which has created alarming clinical situations in the treatment of infections. Many reports show that gram-negative bacteria have a higher resistance to plant extracts than gram-positive bacteria. This may be due to the difference in their cell wall structures (Paz et al., 1995; Vlietinck et al., 1995; Kudi et al., 1999; Palambo and Semple, 2001).

Hence it has become necessary for the search of new antimicrobial agent from other sources, the most convenient natural source is the plants as they produce a variety of compounds to protect themselves against various pathogens, may be because of this reason in traditional medicine plants are being used to treat chronic as well as acute infectious diseases.

Medicinal plants have been used for its antibacterial, antifungal and antiviral activities from many decades in different parts of the world (Ali et al., 1998; Barbour et al., 2004; Yasunaka et al., 2005).The antimicrobial compounds found in plants may prevent bacterial infections by different mechanisms than the commercial antibiotics and therefore may have significant value in treating resistant microorganism strains (Eloff, 1999).

Clematis gouriana Roxb., is a woody climber belongs to the family Ranunculaceae. It is widely used in Ayurveda for the treatment of various ailments. Whole plant is poisonous, stem and leaves are bitter, the juice of freshly crushed leaves and stems has a vesicant blistering action.

Whole plant juice is used is to treat cold, headache, for wound healing, infections. Leaf extract is used to treat eczema, boils, itches, also applied to scabies, cuts and wounds, powdered leaves are used as snuff for sinusitis.. Flowers are used as insecticides. Roots decoction is given to treat stomachache (CRC World Dictionary of Medicinal and Poisonous Plants). Aerial parts and roots contain a quaternary aporphine alkaloid, magnofluorine. The leaves yield protoanemonin, a fungitoxic compound. Some researchers have proved its efficacy as antimicrobial agents (Sankar Narayan Sinha 2006 ), anti ulcerative and hepato protective activity (Kulkarni A. S et al 2012), anti inflammatory activity (Gulnaz.A.R et al 2014 ). In the present study different extract of Clematis gouriana Roxb flower was assessed for its phyto constituents and in vitro antimicrobial activity against MDR oral pathogens to provide scientific validation to this plant.

\section{Materials and Methods}

\section{Plant Collection}

The Healthy disease free plant Clematis gouriana Roxb was collected, from Western Ghats. The plant was identified and authenticated at National Ayurveda Dietetics Research Institute Bangalore, (voucher no: RRCBI- 1194). The flowers were separated from the plants, washed, shade dried at room temperature and then homogenized to fine powder of a 30 mesh sizes and stored in airtight bottles at $4^{\circ} \mathrm{C}$.

\section{Extraction of Plant Material}

About 50gm of dried flower powder was subjected to extraction by a hot percolation method with different solvent in their increasing polarity (Chloroform, ethyl acetate, ethanol water respectively), in Soxhlet apparatus. Extraction step was carried out until the extractive becomes colorless, the extract was concentrated by using flash evaporator and the dried extracts were stored at $4^{\circ} \mathrm{C}$ for further study. 


\section{Phytochemical Screening}

The secondary metabolites like, alkaloids, flavonoids, phenols, tannins, etc were assessed as per the standard procedures. (Gulnaz.A.R and Savitha.G. 2013)

\section{Antibacterial Assay}

\section{Microorganisms Tested}

Oral pathogenic organisms were isolated from clinical samples (Department of Microbiology, Farooqia Dental College and Hospital Mysore, India). Four multi drug resistant oral pathogens $S$. aureus, E. coli, Lacto bacillus, and E.fecalis, are used in this study.

\section{Antimicrobial Activity by disc Diffusion Method}

The disc diffusion assay methods was used to determine antimicrobial efficacy briefly, the inoculums of microorganisms was adjusted to 0.5 McFarland standard, diluted bacterial culture $(100 \mu \mathrm{l})$ was spread over nutrient agar plates with a sterile swab. 100 $\mu l$ of the each extracts were applied to each filter paper disc (Whatman No. 1, $6 \mathrm{~mm}$ diameter.) and allowed to dry before being placed on the agar plate. Each extract was tested in triplicate and the plates were inoculated at $37^{\circ} \mathrm{C}$ for $24 \mathrm{hrs}$. Antimicrobial activities were evaluated by measuring inhibition zone diameters (NCCLS).

\section{MIC by 96 well Resazurin based Microtiter Dilution}

Resazurin based micro titer dilution assay was used to determine MIC. Under aseptic conditions the first row of micro titer plate was filled with $50 \mu \mathrm{l}$ of test materials in $10 \%(\mathrm{v} / \mathrm{v})$ DMSO. All the wells of micro titer plates were filled with $50 \mu \mathrm{l}$ of nutrient broth. Two fold serial dilution (through out the column) was achieved by starting transferring $50 \mu 1$ test material/standard antibiotic from first row to the subsequent wells in the next row of the same column and so that each well has $50 \mu \mathrm{l}$ of test material/ standard antibiotic in serially descending concentrations. $15 \mu \mathrm{l}$ of Resazurin solution (as indicator) was added in each well. Finally the inoculums of microorganisms were adjusted to $0.5 \mathrm{Mc}$ Farland standards a volume of $15 \mu \mathrm{l}$ of the bacterial and fungal suspension added. Each plate was wrapped loosely with cling film to avoid the dehydration of bacterial culture. The plates were incubated in temperaturecontrolled incubator at $37^{\circ} \mathrm{C}$ for $24 \mathrm{hrs}$. The color change in the well was observed visually. Any color change observed from purple to pink or colorless was taken as positive. The lowest concentration of plant leaf extract at which color change occurred was recorded as the MIC value. (Gulnaz.A.R and Savitha.G 2013.)

\section{Statistical Analysis}

The result were express as Mean \pm SEM. Statistical analysis was carried out using one way ANOVA followed by Dunnett's multiple comparison tests.

\section{Results and Discussion}

Medicinal plants are potential sources to cure various diseases. In contrast to synthetic pharmaceuticals phyto medicines show their curative effects through the additive or synergistic action of several chemical compounds acting at single or multiple target sites associated with a physiological process. This synergistic or additive pharmacological effect can be beneficial by eliminating the problematic side effects (Raja and Pugalendi, 2010). The therapeutic benefit of medicinal plants is often attributed to their antioxidant properties (Ljubuncic et al., 2006). 
The preliminary phytochemical screening of the present study revealed the presence of many important compounds which are presented in table-1.

Table.1 Phytochemical Analysis of Ethanolic Extract of Clematis gouriana Roxb Flower

\begin{tabular}{lllll}
\hline Phyto component & CGF C & CGF EA & CGF E & CGF W \\
\hline Alkaloids & + & + & + & + \\
Flavonoids & + & + & + & + \\
Tannins & - & + & + & - \\
Phenol & - & + & + & + \\
Coumarin & - & + & + & - \\
Emodin & - & + & + & + \\
Steroid & - & + & + & - \\
\hline
\end{tabular}

Table.2 In vitro Antibacterial Activity (Inhibitory Zone in Millimeter) of Different Extracts of Clematis gouriana. Roxb Flower against MDR Oral Pathogens

\begin{tabular}{lcccc}
\hline Antimicrobial disc & S. aureus & $\begin{array}{c}\boldsymbol{E} \text {. coli } \\
\text { Zone of inhibition/ mm }\end{array}$ & $\begin{array}{c}\boldsymbol{E} \text {. fecalis } \\
\text { S. mutants }\end{array}$ \\
\hline Amoxicillin-Clavulanic acid 30 & $\mathrm{R}$ & $\mathrm{R}$ & $\mathrm{R}$ & $\mathrm{R}$ \\
Cefixime & $\mathrm{R}$ & $\mathrm{R}$ & $\mathrm{R}$ & $\mathrm{R}$ \\
Amikacin & $7 \pm 0.15$ & $8 \pm 3.10$ & $7 \pm 4.50$ & $9 \pm 7.0$ \\
Tetracyclin & $07 \pm 0.10$ & $07 \pm 8.25$ & $\mathrm{R}$ & $\mathrm{R}$ \\
Doxycyline & $08 \pm 5.18$ & $08 \pm 0.11$ & $\mathrm{R}$ & $07 \pm 0.46$ \\
chlorhexidine & $07 \pm 4.10$ & $08 \pm 0.46^{\mathrm{c}}$ & $07 \pm 0.1$ & $07 \pm 0.1$ \\
CGF C & $08 \pm 0.80$ & $07 \pm 7.10$ & $07 \pm 0.0$ & $07 \pm 0.4$ \\
CGF EA & $07 \pm 7.10$ & $07 \pm 4.15$ & $08 \pm 2.38^{\mathrm{c}}$ & $09 \pm 0.4^{\mathrm{b}}$ \\
CGF E & $12 \pm 0.31^{\mathrm{b}}$ & $13 \pm 0.3^{\mathrm{a}}$ & $11 \pm 0.4^{\mathrm{b}}$ & $12 \pm 0.0^{\mathrm{a}}$ \\
CGF W & $09 \pm 0.60^{\mathrm{b}}$ & $08 \pm 0.27^{\mathrm{c}}$ & $09 \pm 1.10^{\mathrm{b}}$ & $10 \pm 6.0^{\mathrm{b}}$ \\
\hline
\end{tabular}

Table.3 Minimum Inhibitory Concentration (MIC) of Different Extracts of Clematis Gouriana. Roxb Flower by Resazurin Micro Titre-plate Assay

\begin{tabular}{lcccc}
\hline Antimicrobial source & S. aureus & $\begin{array}{c}\text { E. coli } \\
\text { (MIC, mg/ml) }\end{array}$ & $\begin{array}{c}\text { E. fecalis } \\
\text { S. mutants }\end{array}$ \\
\hline Amoxicillin-Clavulanic acid 30 & - & - & - & - \\
Cefixime & - & - & - & - \\
Amikacin & - & - & - & - \\
Tetracyclin & $5.0 \pm 0.50$ & $5.0 \pm 0.7$ & - & - \\
Doxycyline & $2.5 \pm 1.25^{\mathrm{c}}$ & $5.0 \pm 0.57$ & - & $5.0 \pm 4.0$ \\
Chlorhexidine & $5.0 \pm 3.40$ & - & $5.0 \pm 0.38$ & $5.0 \pm 8.5$ \\
CGF C & $1.75 \pm 0.37^{\text {a }}$ & $5.0 \pm 4.50$ & $5.0 \pm 0.45$ & - \\
CGF EA & $5.0 \pm 0.00$ & - & $5.0 \pm 5.05$ & $2.5 \pm 7.9$ \\
CGF E & $1.75 \pm 0.7^{\text {a }}$ & $0.875 \pm 2.0^{\mathrm{a}}$ & $2.5 \pm 8.0^{\mathrm{b}}$ & $0.875 \pm 0.6^{\mathrm{a}}$ \\
CGF W & $5.0 \pm 3.0$ & - & $2.5 \pm 0.0^{\mathrm{c}}$ & $2.5 \pm 0.35^{\mathrm{c}}$ \\
\hline
\end{tabular}

(+: Present, - : Absent R: Resistant / No activity, CGF C: Chloroform extract, CGF EA: Ethyl acetate extract, CGF E: ethanol extract, CGF W: water extract.). The values are means of triplicates \pm standard deviation, the values followed by different superscript differ significantly ${ }^{\mathrm{a}} p<0.001,{ }^{\mathrm{b}} p<0.01,{ }^{\mathrm{c}} p<0.05$ 
All the phyto constituents tested were found in the ethanol and ethyl acetate extract. In water extract tannins, coumarins, steroid was absent. In Chloroform extract only alkaloids and flavonoids were detected.

\section{Antibacterial Activity}

In the present study, we have evaluated the potential of different extracts of Clematis gouriana Roxb flower for its antimicrobial activity against MDR oral pathogens in terms of zone of inhibition and MIC values. The results are presented in table: (2-3). Potent activity was seen in ethanol extract against E. coli with the zone of inhibition of $13 \mathrm{~mm}$ and the MIC value of $0.875 \mathrm{mg} / \mathrm{ml}$ followed by against both $S$. aureus and $S$. mutants $(12 \mathrm{~mm})$ with MIC value of $0.1 .75 \mathrm{mg} / \mathrm{ml}$ and $0.875 \mathrm{mg} / \mathrm{ml}$ respectively, Antimicrobial activity was not found with Amoxicillin-Clavulanic acid 30 and Cefixime standard antibiotics against all the MDR oral pathogens. Both E. fecalis and $S$. mutants were resistance to the standard antibiotics Tetracyclin, E. fecalis was resistance to the standard antibiotics Doxycyline also.

In conclusion, the phyto chemicals/ secondary metabolites possess good, antioxidant activities and has been reported to exhibit various biological activities such as antimicrobial, anthelminthic, antiinflammatory etc. Several researchers have also screened many Indian medicinal plants for their phytchemicals (Jain et al., 2010, Karthishwaran et al., 2010).

The antimicrobial activity is contributed by essential oils, flavonoids, tritepenoids and other natural poly phenolic compounds found in the plants (Ramkumar et al 2007). The result of present investigation clearly indicates that the antibacterial activity varies with the solvent and the potent antimicrobial activity of ethanol against MDR oral pathogens may be due presence of various phyto constituents.

\section{References}

Ali, M. S., Mahmud, S., Perveen, S., Rizwani, G. H., and Ahmad, V. U. (1999).Screening for the antimicrobial properties of the leaves of Calophyllum inophyllum Linn. J. Chem. Soc. Pak. 21, 174-178.

Barbour, E.K., Al Sharif, M., Sagherian, V.K., Habre, A.N., Talhouk, R.S., Talhouk, S.N. (2004). Screening of selected indigenous plants of Lebanon for antimicrobial activity. J. Ethnopharmacol. 93:1-7.

Eloff, J.N.(1999). The antibacterial activity of 27 Southern African members of the Combretaceae. S. Afr. J Sci. 95: 148-152.

Gulnaz,A.R., Anusuya, M.R., Husna Almas,Gururaj,R., Savitha,G., Invitro Anti-Inflammatory activity and Phytochemical analysis of ethanolic extract of Clematis Gouriana Roxb leaf (UGC sponsored national level conference at Sarada Vilas College Mysore Recent Trends in Bioorganic chemistry and its applications to society-RTBAS 2014 ISBN :978-81930115-0-8. Page: 46-50.

Gulnaz,A.R., Savitha,G., (2013), Evaluation of Antimicrobial Activity of Leaf and Stem Extracts of Sidda Medicinal Plant Sida cordata: International Journal of Medicine and Pharmaceutical Sciences (IJMPS) 3(3), 39-50.

Gulnaz,A.R., Savitha,G., (2013). Phytochemical evaluation of leaf and stem extracts of Siddha medicinal plant: Sida cordata Journal of Evolution of Medical and Dental Sciences, 2, (15), (2514-2521). 
Jain, Avijeet, J., Neetesh. J., Jain, D.K. and Neelam, B., (2010). Phytochemical investigation and evaluation of invitro free radical scavenging activity of Tabernaemontana divaricata Linn. Natural Product research 15. 330-334.

Karthishwaran, K., Mirunalini, S., Dhamidharan, G., Krishnaveni, M. and Arulmozhi, V. (2010). Phytochemical investigation of methanolic extract of the leaves of Pergularia daemia. Journal of Biological Science, 10 (3), $242-246$.

Kudi, A.C., Umoh, J.U., Eduvie, L.D., Gefu, J. (1999). Screening of some Nigerian medicinal plants for antimicrobial activity. J. Ethnopharmacol., 67: 225228.

Kulkarni A. S.,Vijaya Raghavan C.,Patil D.M.,Polyherbal mixture Protects against Ethanol- Induced Gastric Ulcers and liver necrosis in Rats. Journal of Pharmacy Research 2012, 5(8), 4169-4171.

Ljubuncic, P., Dakwar, S., Portnaya, I., Cogan, U., Azaizeh, H. and Bomzon, S. (2006). Aqueous extracts of Teucrium polium possess remarkable antioxidant activity in vitro,

National Committee for Clinical Laboratory Standards (NCCLS). Performance standard for antimicrobial disk susceptibility test. Approved standard NCCLS document M2-A7. Wayne Pa 2000

Palombo, E. A., Semple, S. J., (2001). Antibacterial activity of traditional
Australian medicinal plants. J. Ethnopharmacol. 77, 151-157.

Paz, E.A., Cerdeiras, M.P., Fernandez, J., Ferreira, F., Moyna, P., Soubes, M., VS, zquez, A., Veto, S. and Zunino, L. (1995). Screening of Uruguayan medicinal plants for antimicrobial activity. Journal of Ethnopharmacology 45, 6770.

Raja, B. and Pugalendi, K.V. (2010). Evaluation of antioxidant activity of Melothria maderaspatana in vitro, Cent. Eur. J. Biol., 5, 224-230.

Ramkumar, K.M., Rajaguru, P., Latha, M., Ananthan, R., (2007). Ethanol extract of Gymnema montanum leaves reduces glycoprotein components in experimental diabetes. Nutr. Res. 27, 97-103.

Sankar Narayan Sinha., Phytochemical analysis and antibacterial activity of Clematis gouriana Roxb. Int.J.Pharm.Anal. Vol: 2 Issue:5 Page:399-401

Vlietinck, A.J., Van Hoof, L., Tott, J. (1995).Screening of hundred Rwandese medicinal plants for antimicrobial and antiviral properties. J. Ethnopaharmacol, 46: 31-47.

Yasunaka, K., Abe, F., Nagayama. A., Okabe, H., Lozada-Pérez, L., LópezVillafranco, E., Muñiz, E.E., Aguilar, A., Reyes-Chilpa, R. (2005). Antibacterial activity of crude extracts from Mexican medicinal plants and purified coumarins and xanthones. $\mathbf{J}$ Ethnopharmacol 97: 293-299.

\section{How to cite this article:}

Yogesh, B.G., P.Sheshadri, N. Anees Ahmed, A.R.Gulnaz and Vatsala, R. 2016. Phytochemical Analysis and Antimicrobial Activity of Different Extracts of Clematis gouriana. Roxb Flower on Multi Drug Resistance oral Pathogens. Int.J.Curr.Microbiol.App.Sci. 5(3): 686-691. doi: http://dx.doi.org/10.20546/ijcmas.2016.503.081 